\title{
Congresses, Meetings, Societies
}

\section{VII ${ }^{\mathrm{e}}$ Colloque international hippocratique, Madrid 24-29 septembre 1990}

Depuis 1972, qui vit l'organisation du $1^{\text {er }}$ Colloque hippocratique à l'Université de Strasbourg grâce à l'initiative du grand hippocratisant Paul Bourgey et de son disciple Jacques Jouanna, ces colloques se sont succédés régulièrement selon le rythme triennal qui avait été prévu à l'origine. Mons, Paris, Lausanne, Berlin, Québec et enfin Madrid attestent de la dimension internationale que ces réunions scientifiques ont acquise. Mais si les premières éditions réunissaient un nombre relativement restreint de spécialistes, l'engouement qui entoure depuis quelques années les études consacrées à la médecine dans l'Antiquité grecque et romaine pose désormais aux organisateurs de difficiles problèmes. C'est ainsi que le professeur Lopez Ferez, qui avait la lourde tâche de mettre sur pied la $7^{\mathrm{e}}$ édition dans les locaux de l'Universidad nacional de educación a distancia (Madrid) c'est trouvé devant un programme de près de soixante-cinq communications d'une demi-heure (à quoi s'ajoute la discussion) à répartir sur à peine huit demi-journées. Il n'y avait dès lors d'autre solution que l'organisation de sessions parallèles malgré les inconvénients que cela représente pour les participants placés souvent devant des choix difficiles. Le nombre des communications interdit évidemment d'en donner la liste ici. Disons simplement que la décision de ne pas fixer de thème aux travaux du colloque a entraîné une très grande variété dans les communications, qui traitaient de doctrine, de terminologie, de fonction littéraire, d'esthétique, d'histoire, de symbolisme etc. Mais cette variété a eu l'avantage de montrer - et cela de manière très stimulante - la multiplicité des approches actuelles dans les études hippocratiques.

Philippe Mudry 


\section{Deutsche Gesellschaft für Geschichte der Nervenheilkunde}

Am 12. Januar 1990 wurde in Würzburg die Deutsche Gesellschaft für Geschichte der Nervenheilkunde gegründet. In ihr haben sich Wissenschaftler aus Deutschland und den angrenzenden deutschsprachigen Ländern zusammengefunden, um die Erforschung der Geschichte der Psychiatrie, Neurologie, Neurochirurgie und klinischen Psychologie zu fördern. Gleichzeitig will die Gesellschaft ein Band zwischen den sich immer weiter auseinander lebenden nervenheilkundlichen Disziplinen darstellen und die gemeinsamen Wurzeln betonen. Sitz der Gesellschaft ist Würzburg. Präsident der Gesellschaft ist Herr Prof. Dr. K.-A. Bushe, Direktor der Neurochirurgischen Universitätsklinik Würzburg. Seine Stellvertreter sind Herr Prof. Dr. Dr. G. Keil, Vorstand des Institutes für Geschichte der Medizin, und Herr Prof. Prof. h. c. Dr. G. Nissen, Direktor der Klinik für Kinder- und Jugendpsychiatrie der Universität Würzburg. Auskunft erteilt Herr Dr. M.Lanczik, Psychiatrische Universitätsklinik, Füchsleinstr. 15, D-8700 Würzburg.

\section{Museum Boerhaave, Leiden}

In September 1991 the Sir Thomas Browne Institute and the Department of Medical History of the Leiden University, the Netherlands, in cooperation with the Leiden Museum Boerhaave, intend to organize a three-day symposium on the subject of scientific communication and exchange between Great Britain and Europe during the seventeenth and early eighteenth centuries. The conference will be held in the Museum Boerhaave, which in 1991 re-opens to the public on the new premises of the historic Caecilia Hospital.

The symposium will focus on four main questions: 1. How did the diffusion of new theories in the natural sciences from England to the continent and vice versa take place? 2 . What circuits of communication were in operation? 3. How was scientific knowledge and information, including know-how and new technologies, transferred? 4. What was the role of the individual in this scientific exchange? Papers will be presented by a number of speakers from various European countries.

Further details can be obtained from Mrs. M. Fournier, Museum Boerhaave, P. O. Box 11280, 2301 EG Leiden, The Netherlands. 


\section{Julius-Hirschberg-Gesellschaft}

Die Julius-Hirschberg-Gesellschaft - deutschsprachige Gesellschaft für Geschichte der Augenheilkunde - führt von Donnerstag, 24. Oktober bis Sonntag, 27. Oktober 1991 ihre 5. Tagung in Dresden durch. Neben dem wissenschaftlichen wird auch ein reiches kulturelles Programm geboten. Interessenten melden sich am besten so bald wie möglich bei Herrn Prof. Dr. med. habil. E. Marré (wissenschaftliche Leitung) oder Herrn PD Dr. A. Walther (organisatorische Leitung).

Adresse:

Sekretariat der Klinik für Augenheilkunde

Medizinische Akademie «Carl Gustav Carus»

Fetscherstr. 74

D-0-8019 Dresden 